\title{
ECB monetary expansions and euro area TARGET2 imbalances: a balance-of-payment- based decomposition
}

\author{
Marcello Minenna* \\ Commissione Nazionale per le Società e la Borsa (CONSOB), Rome, Italy \\ Giovanni Dosi \\ Scuola Superiore 'Sant'Anna,' Pisa, Italy \\ Andrea Roventini \\ Scuola Superiore 'Sant'Anna,' Pisa, Italy and OFCE-Sciences Po, Sophia-Antipolis, France
}

The recent financial literature seems to have reached a consensus about the influence of European Central Bank (ECB) unconventional monetary policies in explaining the multiple divergent trends of TARGET2 (T2) balances in the eurozone from 2010 and the ensuing segregation of risks in each national economy. According to the ECB, 'mechanical' effects in the accounting of government bonds explain the explosion of $T 2$ balances. Divergence could therefore not be attributable to a 'capital flight' from peripheral economies towards northern Europe. Such an explanation does not seem to fit well with the analysed cases of Italy, Spain, and Germany. A decomposition of the T2 balances through the analysis of the financial accounts of the balance of payments shows indeed that the deterioration in the balances of Italy and Spain is mainly due to a shift of private-sector financial wealth from government securities to foreign assets (bonds, shares, and mutual funds). In the case of Germany, the abnormal growth of T2 balances is mainly attributed to the persistent influence of current-account surpluses reaching 6-8 percent of GDP and increasing due to the indirect effects of quantitative easing policies on the exchange rate between the euro and the other major international currencies.

Keywords: capital flows, payment system, financial crisis, quantitative easing, interbank lending

JEL codes: E42, E44, E52, E58, F32, F34

\section{INTRODUCTION}

In this work we study the dynamics of eurozone TARGET2 (T2) imbalances and their consequences by performing a decomposition of T2 balances through the analysis of the financial accounts of the balance of payments which track all incoming and outgoing capital flows from the country of reference. T2 is the current Trans-European Automated Realtime Gross settlement Express Transfer system, that is, an intra-European funds transfer system run on a single shared IT platform, the settlement net values of which are calculated daily on a bilateral or multilateral gross basis. In September 2017, the eurozone's T2 net

* Corresponding author: Email: m.minenna@consob.it.

Received 5 February 2018, accepted 14 April 2018 
balances continued to diverge, reaching record levels never experienced before: for Italy, -€433 billion; for Spain, -€383 billion; while Germany records a huge surplus of $€ 835$ billion, well above the peaks registered during the 2011-2012 eurozone crisis in peripheral countries. The European Central Bank (ECB) has also seen its deficit widen to $-€ 215$ billion due to quantitative easing $(\mathrm{QE})$ purchases. Around 10 percent of QE assets are risk-shared between eurozone countries and thus are accounted as an ECB 'debt' towards national central banks (NCBs).

This unusual accounting confirms the complex technicalities that are involved and that continue to veil a clear explanation of the driving components of this accounting method employed by European central banks.

Academic research on the importance of T2 balances has progressed considerably since the disputed work of Sinn (Sinn/Wollmershäuser 2012), who attempted to shed light on the relationship between the current accounts and the T2 balances of eurozone countries. A surplus in the current account should lead to a positive T2 net balance, and vice versa. Within this perspective, Sinn considers that T2 balances are a 'stealth bail-out' of peripheral countries by the creditor central banks. Indeed, a subsequent default of the debtor central bank would turn into a net loss for the Eurosystem, to be absorbed jointly by all the remaining members (risk mutualization or risk-sharing). Whelan (2012; 2014) contested this view, pointing out that any central bank can always operate with 'negative equity,' that is, it could offset losses by 'printing money,' without fiscal transfers from the taxpayers. Szécsényi (2015) concludes that T2 assets and liabilities could eventually lead to losses in the extreme case of a euro break-up, but these should be much lower than what the raw net imbalances suggest. Nonetheless, a part of the academic and financial community seems to acknowledge that diverging net balances in the last two years are driven mainly by financial transactions (Borio/Disyatat 2015).

\section{HOW TARGET2 WORKS}

The gross settlement system TARGET2 is the operating arm of the European financial system, which allows member countries to efficiently regulate interbank credit. This is a technical tool which, through subsequent compensations, allows the quick transfer of financial flows between the different countries of the Eurosystem.

The nodes are the central banks of European countries which choose to adhere to the Eurosystem: basically, if a German bank needs to settle a credit with an Italian bank, it may access an intraday cash account at the Bundesbank and obtain an anticipated payment, while the Italian bank will settle its own balance with the Bank of Italy. At this point, the German central bank will record a credit against the Italian central bank in its accounting books, and vice versa. The credit is not compensated through the direct transfer of flows between the two national central banks because in practice they are nothing more than 'branches' of the ECB.

\section{TARGET2 AND ECB QUANTITATIVE EASING}

Recent findings ${ }^{1}$ have linked the launch of the ECB quantitative easing (QE) with the resumption of the $\mathrm{T} 2$ balance divergence process in the eurozone, after a period (2012-2014) of relative reduction. Also the ECB considers QE as the main driver of

1. See De Nederlandsche Bank (2016), Dor (2016), Meijers/Muysken (2016), ECB (2017), European Parliament (2017), and Minenna (2017). 
the divergent T2 balances among euro area countries. In an official bulletin (ECB 2016), it highlights the linear relationship between the liquidity injected into European financial systems through the purchase of government bonds and the corresponding increase in T2 balances, negative for the peripheral central banks (see Figure 1, overleaf), and positive for Germany and satellite core countries (see Figure 2, overleaf). The dynamics of the T2 balances for other primary economies such as France and Austria seem by comparison stationary and not correlated with the ECB's monetary expansion.

At first glance, the dynamics of $\mathrm{T} 2$ balances reveals that all the new liquidity injected into the financial systems of the peripheral countries have been drained to northern Europe, giving rise to the perception of a 'capital flight.' According to the ECB, such patterns are only apparently capital flights and depend mainly on the mechanics of QE. Indeed, according to the $\mathrm{QE}$ engagement rules, eurozone national central banks acquire government securities from both domestic and foreign entities. When the Bank of Italy for example - buys an Italian government bond from a German enterprise, liquidity flows directly into the German financial system and is negatively/positively accounted for in the T2 balance of the Bank of Italy/Bundesbank. Moreover, the Bundesbank (or the Dutch and Luxembourg central banks) also intermediates between the operations of banks outside the euro area that tends to use its local subsidiaries to make purchases (for example, a British bank involved in purchasing Italian government bonds passing through its German subsidiaries). The ECB Bulletin reports that, at the aggregate level, 80 percent of all purchases were made through cross-border operations of national central banks with foreign entities, while approximately 50 percent of securities purchases within the QE involved residents outside the euro area, thus fueling the growth ${ }^{2}$ of T2 balances in Germany, the Netherlands, and Luxembourg.

However, these aggregate figures are not representative of what is happening in the large economies of Italy and Spain, where the government debt tends to be predominantly held by domestic investors (in Italy about 65 percent of the debt is in national hands, while in Spain this percentage hoovers up around 50 percent). If national central banks will make purchases from domestic and foreign investors using a uniform trading pattern, one should expect that they will grossly respect this subdivision. Thus, the figure of 80 percent is likely to be representative for countries such as Austria, where 85 percent of the debt is actually in foreign hands, but it ought to be considered an overestimate for Italy and Spain.

\section{THE DECOMPOSITION OF T2 BALANCES}

To shed light on the Italian and Spanish financial flows, the net balance of T2 must be analysed as the result of movements in the accounts of the balance of payments (BP), ${ }^{3}$ which track all incoming and outgoing capital flows from the country of reference. Since the BP net value must be zero at all times, the T2 balance will vary in response to a variety of cross-border financial transactions carried out by banks, government, and the non-financial private sector. Let us then decompose the T2 net balances of Italy, Spain, and Germany for the corresponding BoP flows.

2. According to the Bundesbank, '[t]he TARGET2 balance in the Bundesbank's balance sheet is therefore mainly attributable to cross-border transactions which involve banks that participate in TARGET2 via the Bundesbank' (https://www.bundesbank.de/Redaktion/EN/Standardartikel/ Tasks/Payment_systems/target2_balance.html).

3. The International Monetary Fund states in its position manual that the TARGET2 net balance has to be accounted inside the section Financial account - Other investments. See also Annex 3 A3. 46 IntraCUNCBs and CUCB balances, at https://www.imf.org/external/pubs/ft/bop/2007/pdf/bpm6.pdf. 
150 European Journal of Economics and Economic Policies: Intervention, Vol. 15 No. 2

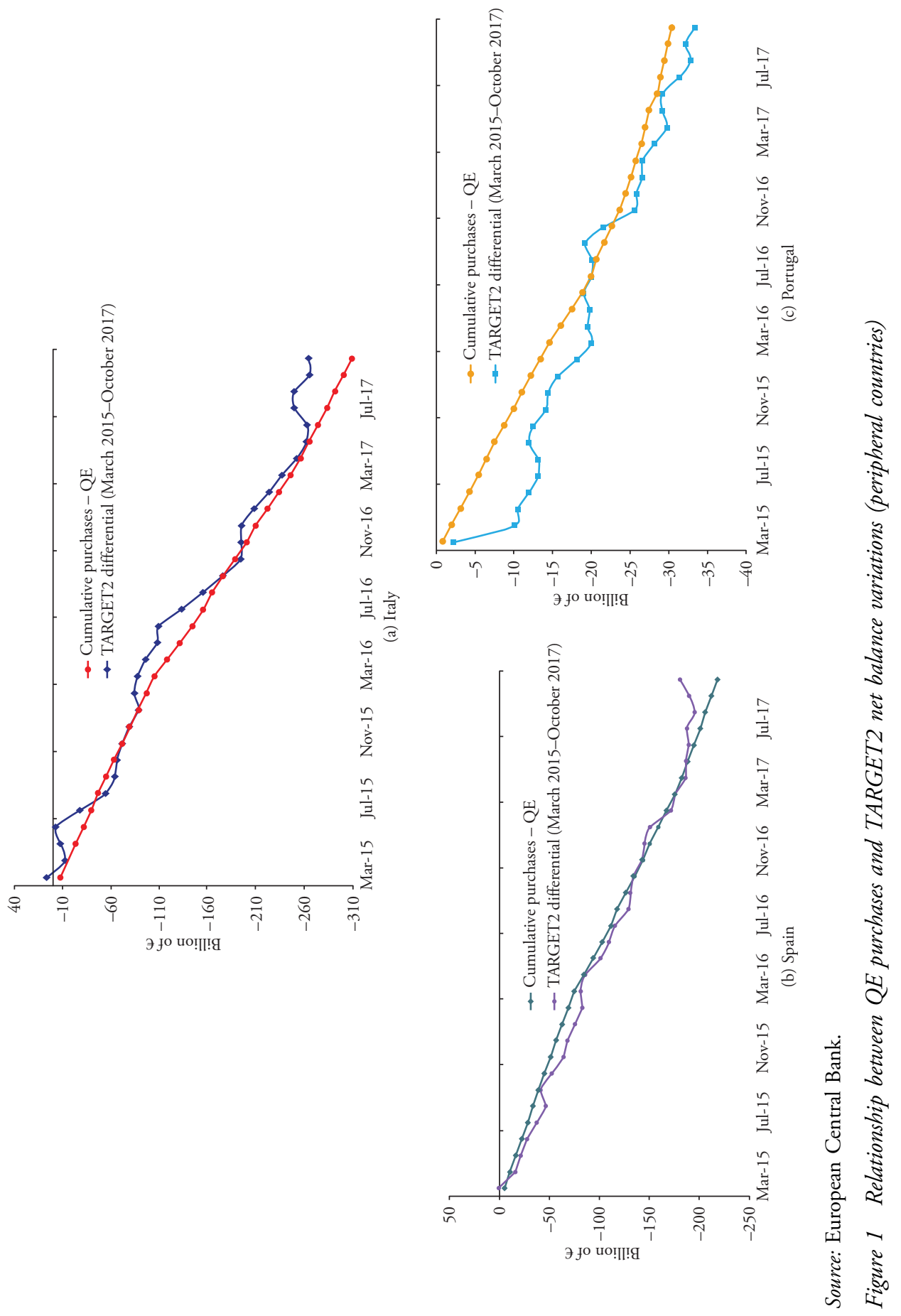



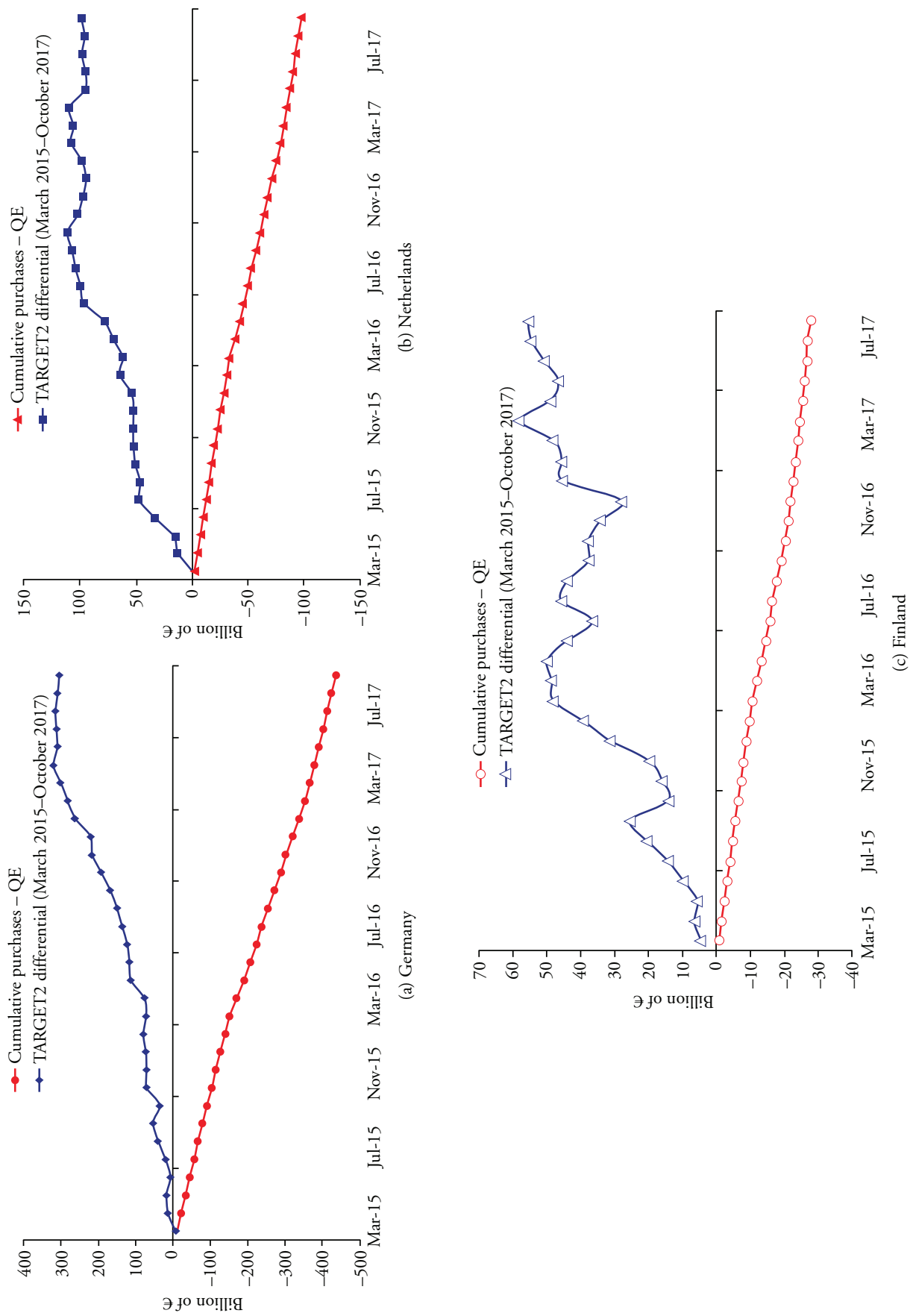

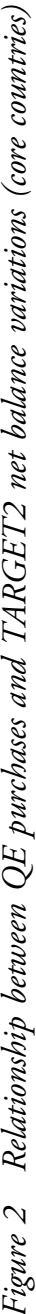




\subsection{Italy}

We start by considering the dynamics of the cumulative balance of foreign investment in Italian government bonds. ${ }^{4}$ The black bars in Figure $3^{5}$ show that between 2011 and 2012, at the height of the Italian debt crisis, core banks have sold a significant amount of Italian government bonds on the secondary market due to the augmented perception of credit risk. The sale of an Italian financial asset from abroad represents a capital outflow for Italy, which is recorded with the sign (-) in the T2 balance. Italian government bonds were then repurchased at low prices by Italian banks thanks to the huge flows of liquidity that they were borrowing via $\mathrm{LTRO}^{6}$ from the ECB. This operation succeeded in securing refinancing to the Italian government, but at the cost of internalizing the sovereign credit risk within the Italian financial system.

At the same time, German banks were reducing their long-term commercial credits towards Mediterranean countries. This phenomenon is captured by the negative growth of white bars representing the cumulated interbank lending of Italian banks. ${ }^{7}$ In 20112012, this lending was decelerating, due to the substantial reduction in the deposits held by foreign banks at Italian banks and the lack of renewal of existing credit lines.

Hence the combined effect of the fire sale of government bonds to Italian banks (black bars) and the contraction of interbank credit (white bars) fully explains the explosion of the T2 balance up to $-€ 280$ billion at the end of 2012 .

In 2013, when LTRO repayments began, the ECB's balance sheet gradually deflated together with the T2 balances of all the major eurozone countries. The divergence of T2 balances resumed in June 2014 when the ECB launched a new loan program for European banks aimed this time at increasing corporate credit (the so-called T-LTRO, targeted long-term refinancing operation).

However, the divergence process in T2 balances accelerates considerably after the launch of QE and the public sector purchase program (PSPP) in March 2015. In September 2017, total purchases had already exceeded $€ 1869$ billion. Only the total assets of the Bank of Italy rose, by $€ 400$ billion in 30 months.

In sync with the launch of the PSPP, a new phenomenon has become the main determinant of deterioration of the Italian T2 balance, namely a reallocation of non-financial privatesector wealth from government bonds to foreign bonds, mutual funds, and shares (dotted bars in Figure 3). From March 2015 to September 2017, over $€ 220$ billion were reinvested by non-financial Italian enterprises in vehicles with legal residence in Luxembourg, the Netherlands, and Germany. Only 20 percent of these can be attributed to Italian entities (through 'round trip' funds). A good number of these transactions were allowed by the monetary policy of the Bank of Italy, which purchased government bonds from private investors, thus providing the necessary financial resources. The flows were too strong to simply be downplayed as a physiological strategy of risk diversification.

During the whole of 2017, conditions of stress were observed again on the Italian banking system, with a reduction in foreign exposure and a progressive reduction of credit

4. The same empirical patterns have recently appeared in a Bank of Italy report 'I saldi TARGET2 e i movimenti dei capitali' (http://www.bancaditalia.it/media/views/2017/target2/index. html).

5. Italy BP - Financial account - Portfolio investment - Liabilities - Debt securities - General government.

6. LTROs (long-term financing operations) - 3-year, 1 percent loans were provided between December 2011 and February 2012 in full allotment for an amount that surpassed $€ 100$ billion.

7. Italy BP - Financial account - Portfolio investment - Liabilities - Monetary financial institutions (MFIs) other than central bank. 

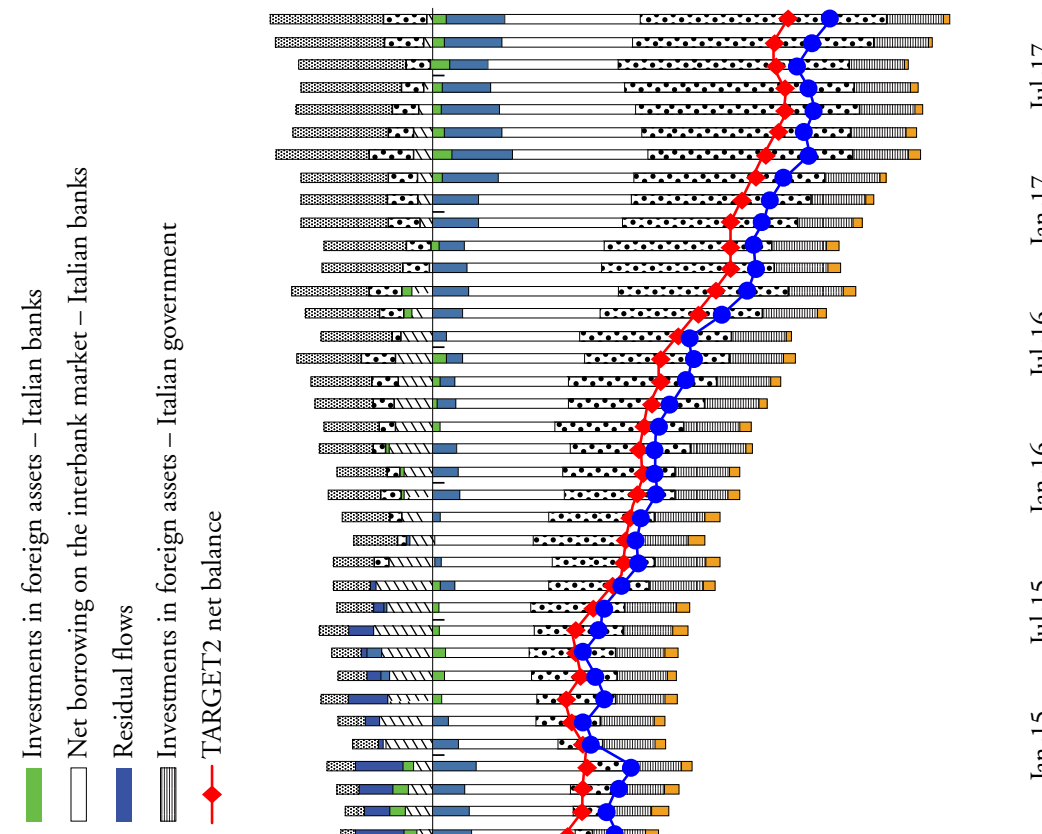

$\stackrel{1}{\Xi}$

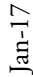

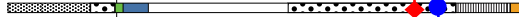

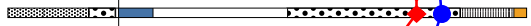

19.......

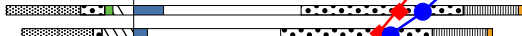

का

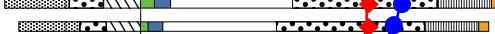

Fध

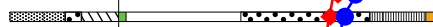

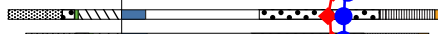

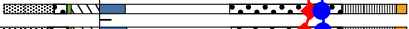

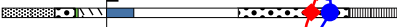

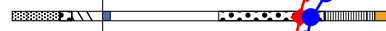

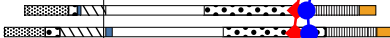

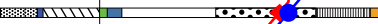

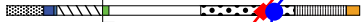

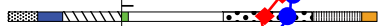

अ:

(10.7)

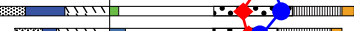

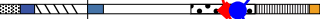

आC:

10\%

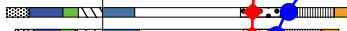

an a

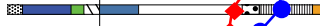

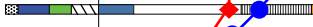

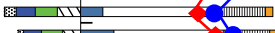

II)

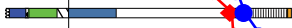

r $\mathrm{N}$ (1)

曽

丞

:

芒范

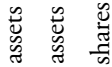

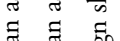

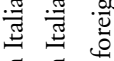

$\Xi . \Xi$.

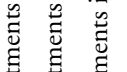

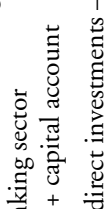

10

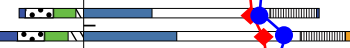

r..n

$\because$ 1

0.011

(10.01

10:011 _

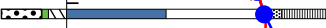

b:.:21N

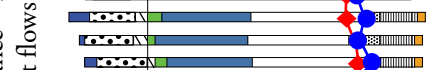

$\because \because \%$ -

$\because \cdots$.

...

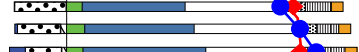

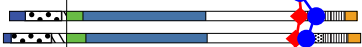

ह.0.

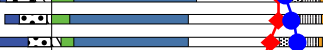

$\because \mathrm{n} / \mathrm{n}$

एव

1.:2:11

ज्ञात 12

0.121

प1

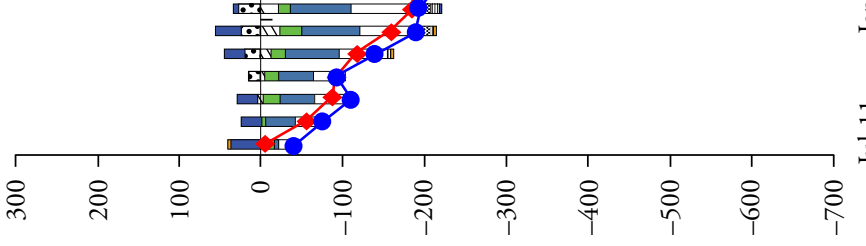

$\frac{6}{\frac{1}{3}}$

章

$\frac{n}{3}$

$\stackrel{n}{\stackrel{n}{*}}$

$\stackrel{\frac{1}{5}}{\stackrel{2}{\Xi}}$

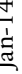

ב⿱亠乂⿰丿亅⿻

i

$\frac{n}{\frac{1}{3}}$

a

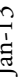

$\frac{2}{3}$

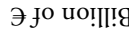


lines (downward trend of white bars). The issuance of a bail-out decree by the government in January 2017 for an amount of up to $€ 20$ billion seems to have stabilized the outflow of capital through the banking channel in the short term (white bars stationary in Figure 3). No large impact on foreign exposure could be attributed to the recent winding-up of Veneto banks, with a government contribution of $€ 17$ billion.

\subsection{Spain}

Similar conclusions can be drawn from the analysis of Spain's balance of payments (see Figure 4). Foreign capital flew back into Spanish government bonds (black bars) after the banking system stabilized through the intervention of the ESM (European Stability Mechanism). In synergy, the recovery of the access to interbank credit by the Iberian institutions (white bars) contributed in 2013-2014 to the stabilization of Spain's negative T2 balance.

However, from early 2015, with the launch of QE, the T2 balance has been getting gradually worse, reaching the record negative values experienced in recent months. In line with the Italian case, three key determinants are responsible for the observed dynamics: the growth of non-financial private-sector foreign investments (dotted bars, $-€ 145$ billion in the 2015-2017 period), the sales of government assets by foreign investors to Banco de España (black bars, - $€ 44$ billion), and the reduction in the quantity of interbank loans obtained by Spanish banks (white bars, $-€ 62$ billion).

\subsection{Germany}

Germany's T2 balance has expanded over time to record values (see Figure 5, overleaf), having already abandoned neutrality conditions during the 2008-2009 financial crisis. In the turbulent period for the peripheral debt markets of 2011-2012, the balance grew positively, due mainly to a steady current-account surplus of 6 to 8 percent of annual GDP (diagonally striped bars).

The ECB's monetary expansion, in particular QE, has also had a major impact on the German T2 balance. Figure 5 shows two channels of transmission, similar to the Italian and Spanish cases, through which the effects of QE are paradoxically compressing the German T2 balance: the reduction in the amount of government bonds held by foreign investors (black bars, $-€ 250$ billion) due to purchases by the Bundesbank, and the contextual growth of non-financial private-sector investment abroad (dotted bars, $-€ 350$ billion).

Nonetheless, the T2 balance rose by about $€ 365$ billion in less than 36 months. The analysis in Figure 5 suggests that the main cause can be attributed to the uninterrupted growth of the cumulative surplus of the current-account ( $€ 830$ billion in the reference period). The acceleration of the growth of the German trade surplus is certainly related to the devaluation of the euro against the major international currencies that has averaged 16 percent between mid 2014 and 2017 and has been, anyway, one of the indirect effects of QE.

For what concerns the weight (undetermined in the ECB's position paper) to be attributed to the Bundesbank role of hub when purchasing securities on behalf of banks outside the euro area, the Bundesbank credits a euro deposit that appears in the passive side of the foreign exposure of the central bank (see Figure $6^{8}$ ). The growth of this financial variable is evidently linked to the purchase of government bonds by the Bundesbank and can

8. Germany BP - External position of the Bundesbank - External liabilities - Other investment Deposits of non-Euro area residents. 

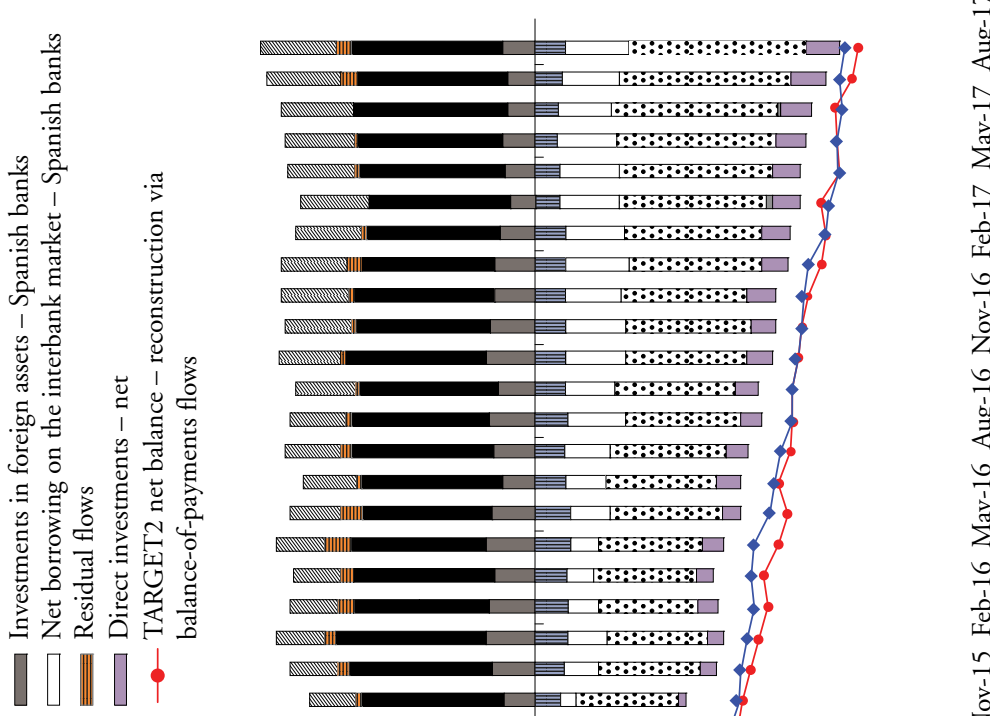

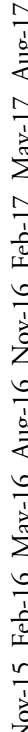
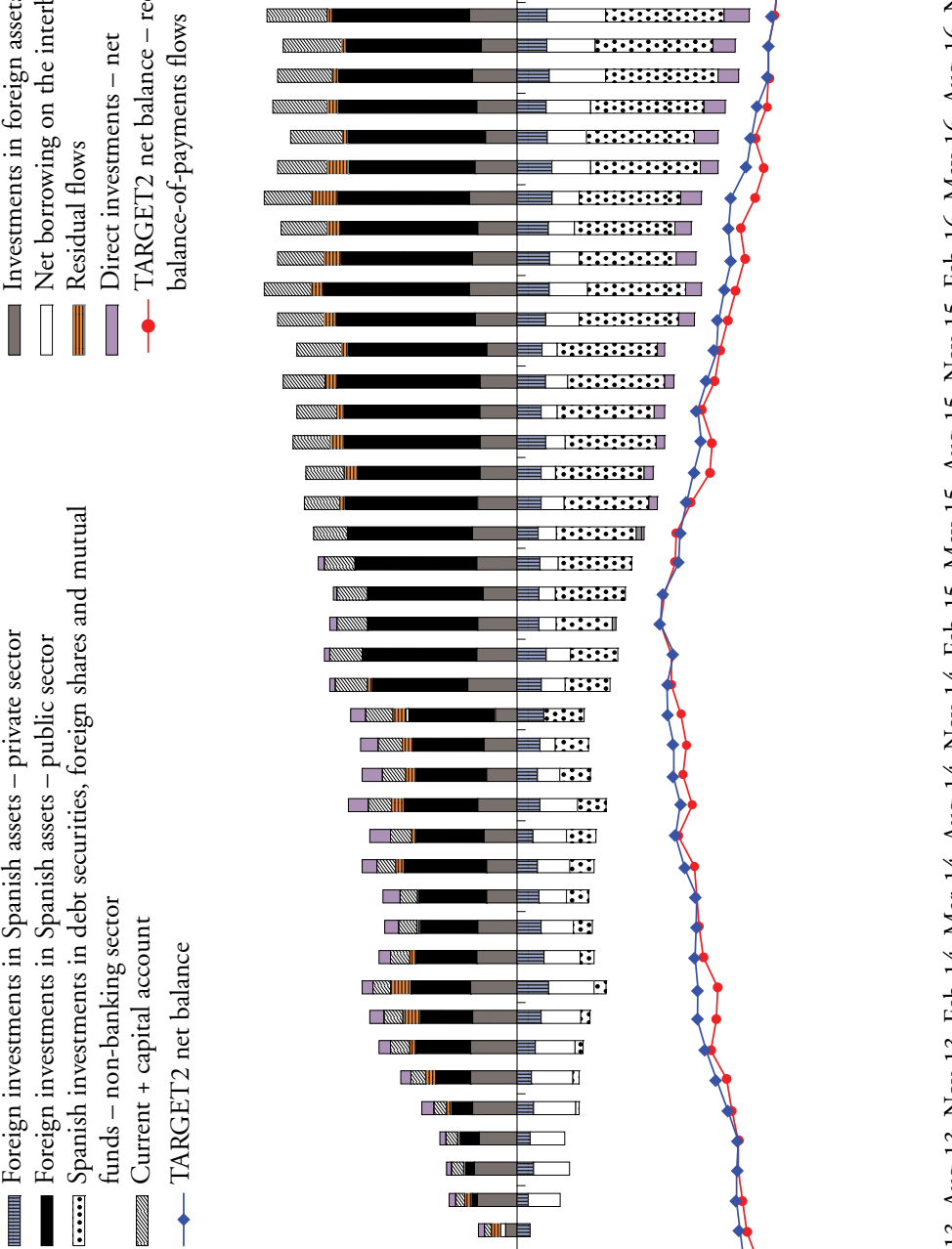

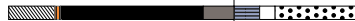

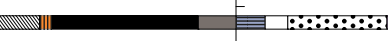

बाmel|

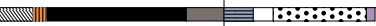

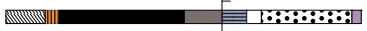

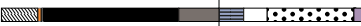

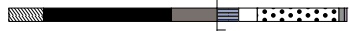

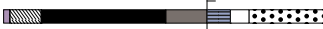

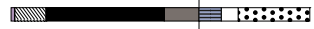

वालाए

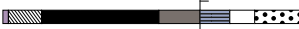

आMाएण

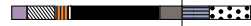

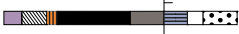

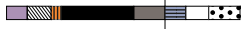

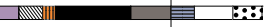

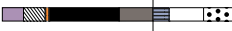

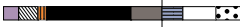

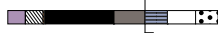

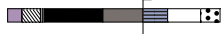

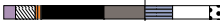

पर्णाIIII -

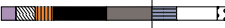

बत्ण

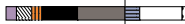

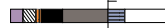

进

速

建叫首

연들

대드

咀梪

怔目

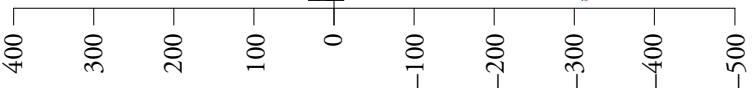

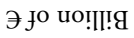


156 European Journal of Economics and Economic Policies: Intervention, Vol. 15 No. 2

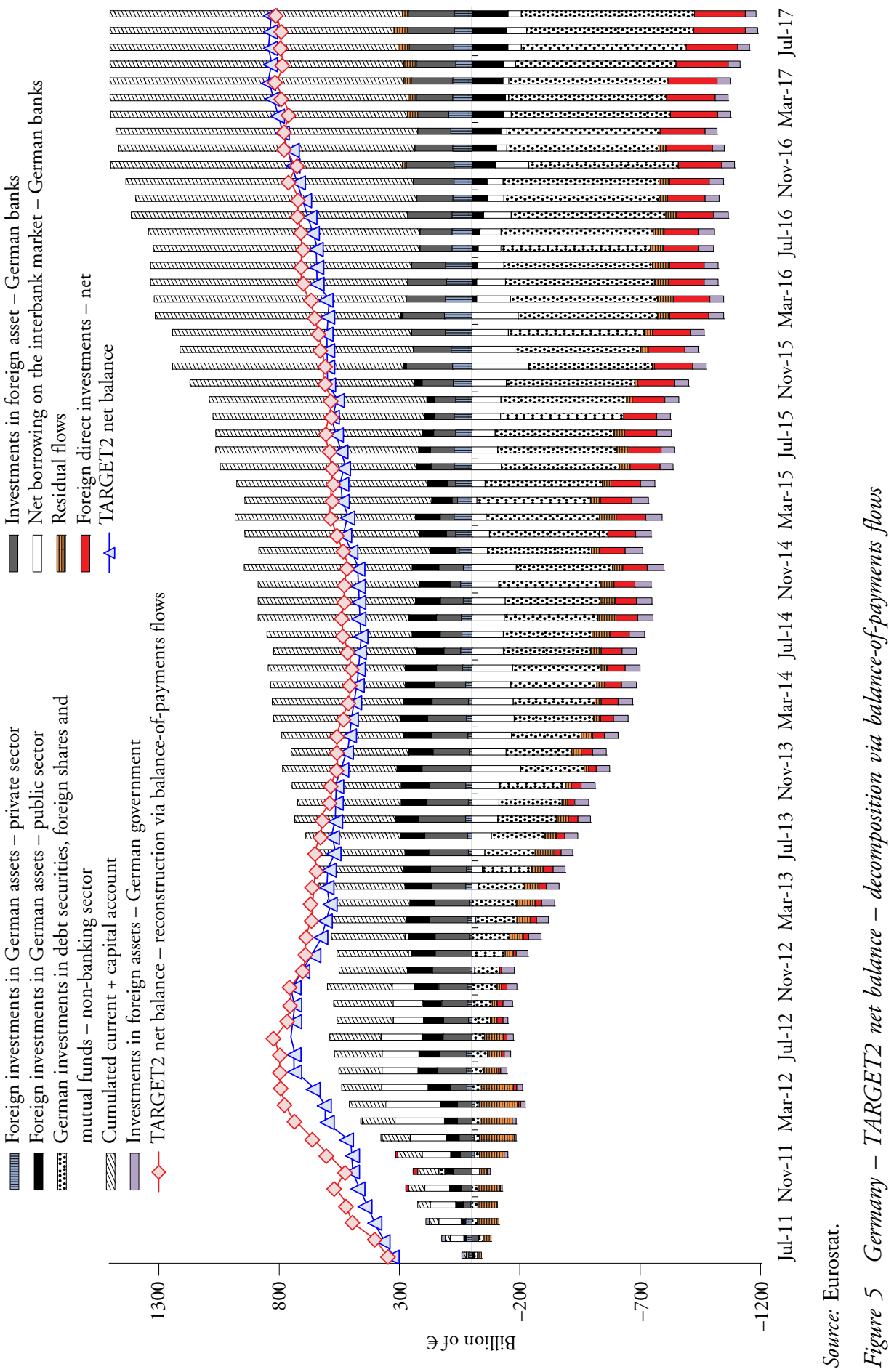




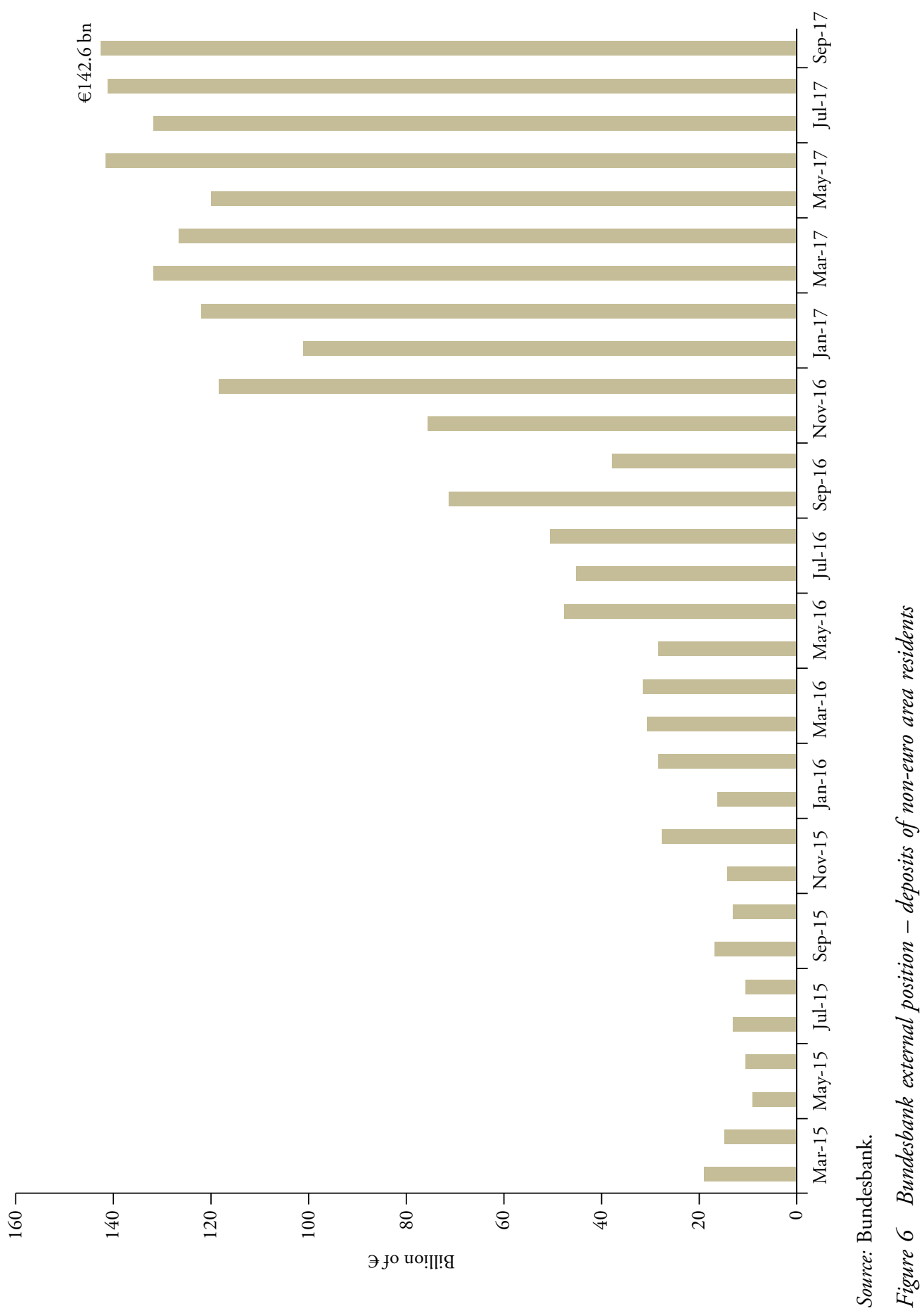


reasonably be explained by the role of intermediary that the German central bank has on behalf of financial institutions residing outside the eurozone.

\section{CONCLUSION}

Diverging T2 balances in the Eurosystem remain a controversial issue, partly due to the technical complexities involved. The recent developments are clearly connected to the liquidity flows injected into the Eurozone financial system by the ECB via QE. The availability of fresh central-bank money and a weaker euro have encouraged banks, firms, and investors to engage in a multitude of cross-border transactions that have inflated T2 accounts of many, but not all, eurozone central banks. According to the ECB, 'mechanical' effects in the accounting of asset purchases by eurozone central banks fully explain the explosion of T2 balances. Divergence could therefore not be attributable to a 'capital flight' from peripheral economies towards northern Europe.

This explanation does not seem to fit well for Italy, Spain, and Germany. Two main phenomena have clearly emerged. In peripheral countries, a shift of private-sector financial wealth from government securities sold to central banks to foreign assets is reflected in rising negative T2 balances. In Germany, the data show the overwhelming impact of current-account surpluses.

After the launch of QE by the ECB, the increasing imbalances in the T2 system show once again - that in the presence of heterogeneous industrial and financial structures among European countries, the European Monetary Union (EMU) does not have any built-in stabilizing mechanisms to foster the convergence of European economies. In such a framework, institutional reforms in the EMU (for example, the banking union, ECB as lender of last resort) and more generally in the European Union architectures (for example, common fiscal policies) are urgently needed to avoid catastrophic consequences (more on this in Minenna et al. 2016).

\section{ACKNOWLEDGMENTS}

The authors thank Marc Lavoie and the participants to the 29th Annual EAEPE Conference (Budapest, 2017). Giovanni Dosi and Andrea Roventini gratefully acknowledge the support by the European Union's Horizon 2020 research and innovation program under grant agreement number 649186 - ISIGrowth. Marcello Minenna thanks his colleague Paolo Verzella for his support in the data collection and analysis.

\section{REFERENCES}

Borio, C., Disyatat, P. (2015): Capital flows and the current account: taking financing (more) seriously, BIS Working Paper No 525.

De Nederlandsche Bank (2016): Target2 imbalances reflect QE and persistent fragmentation within the euro area, in: DN Bulletin, 16 June.

Dor, E. (2016): Explaining the surge of TARGET2 liabilities in Italy: less simple than the ECB's narrative, URL: https://papers.ssrn.com/sol3/papers.cfm?abstract_id=2860545.

ECB (European Central Bank) (2016): TARGET balances and the asset purchase programme, URL: https://www.ecb.europa.eu/pub/pdf/other/eb201607_box02.en.pdf.

ECB (European Central Bank) (2017): The ECB's asset purchase programme and TARGET balances: monetary policy implementation and beyond, in: ECB Economic Bulletin, Issue 3. 
European Parliament (2017): Target (im)balances at record levels: should we worry?, In-depth analysis for the ECON Committee by the London School of Economics, URL: http://www. europarl.europa.eu/cmsdata/131943/MD\%20LSE\%20formatted_FINAL\%20publication.pdf.

Meijers, H., Muysken, J. (2016): The impact of quantitative easing in the Netherlands: a stock flow consistent approach, URL: https://www.boeckler.de/pdf/v_2016_10_22_muysken.pdf.

Minenna, M. (2017): The ECB's story on Target2 doesn't add up, URL: https://ftalphaville.ft.com/ 2017/09/14/2193700/guest-post-the-ecbs-story-on-target2-doesnt-add-up/\#comments.

Minenna, M., Boi, G.M., Verzella, P. (2016): The Incomplete Currency: The Future of the Euro and Solutions for the Eurozone, Somerset, NJ: John Wiley.

Sinn, H.-W.,Wollmershäuser, T. (2012): TARGET loans, current account balances and capital flows: the ECB's rescue facility, in: International Tax and Public Finance, 19(4), 468-508.

Szécsényi, P. (2015): Nature of Target2 imbalance, in: Public Finance Quarterly, 2015/3, 342-356.

Whelan, K. (2012): TARGET2: not why Germans should fear a euro breakup, VoxEU, 29 April, URL: https://voxeu.org/article/target2-germany-has-bigger-things-worry-about.

Whelan, K. (2014): TARGET2 and central bank balance sheets, in: Economic Policy, 29(77), 79-137. 